\title{
Floral Biology: Implications for Fruit Characteristics and Yield
}

\author{
Adolfo Rosati, Silvia Caporali and Andrea Paoletti
}

Additional information is available at the end of the chapter

http://dx.doi.org/10.5772/51727

\section{Introduction}

Floral biology has important practical implications, in addition to its scientific relevance, given that flower characteristics and bloom affect fruit characteristics and yield. Yield derives from fruit quality (e.g. weight) and quantity (i.e. number), which, in turns, depend on flower quantity and quality: flowers must be suitable to become fruits, and then must be pollinated and fertilized, and must set fruits, which must then grow. Not all flowers can do all of this: some flowers, for instance, have aborted ovaries which are partially developed or absent at bloom, depending on when the abortion occurred. Even when still present, these aborted ovaries are not capable of becoming fruits. Normal pistils, may not be pollinated or fertilized, but also fertilized ovaries may drop after some growth, resulting in fruit drop. From 100 flowers, in olive, all the above phenomena result in one to few fruits (Hartmann, 1950). Because of this low fruit set, it is often believed that cultural practices aimed at improving pollination, increasing fruit set or reducing ovary abortion or fruit drop, may lead to increased olive yields.

In the following paragraphs we will analyze in detail some of these passages (i.e. ovary abortion and fruit set) allowing fruit formation from the flower. We will conclude that, in olive, yield is affected mostly by the nutritional status of the tree and the environmental conditions affecting it, which determine the potential yield. To achieve this potential yield, the plant uses a series of compensating mechanisms which make the yield rather independent of flowering or any single subsequent passage (i.e. ovary abortion, fruit set, drop and size).

Firstly, however, we will begin by describing how fruit characteristics, particularly fruit size, are mostly determined by the ovary characteristics at bloom. In the following paragraphs we will see how these ovary characteristics affect ovary abortion and fruit set. Finally we will discuss the apparent redundant flowering in olive, which produces many more flowers than necessary for the yield it can sustain. 


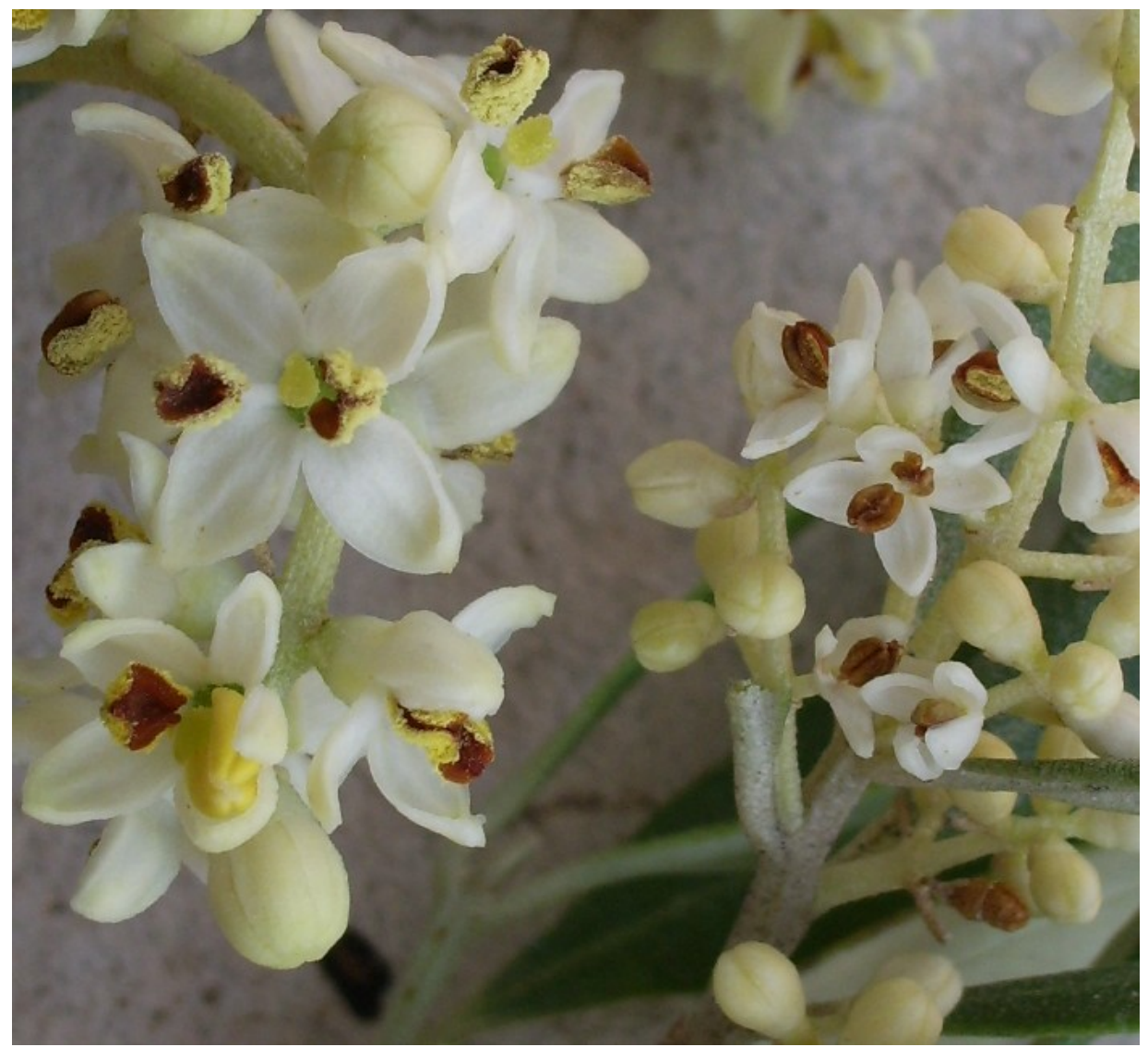

Figure 1. Flower size differs among olive cultivars: Nocellara del Belice, a large-fruited cultivar, on the left, and Koroneiki, a small-fruited cultivar, on the right.

\section{Ovary vs. fruit characteristics}

Fruit size is important commercially and the study of factors affecting it are of great scientific interest. Fruit size depends mostly on the size and number of fruit cells, though intercellular space may be also important (Bertin et al., 2002; Corelli-Grappardelli, 2004). In olive, fruit size differs greatly among cultivars (Barranco, 1999). Both the endocarp and mesocarp contribute to final fruit size differences among cultivars (Hammami et al., 2011).

Fuit size differences across cultivars are mostly due to cell number, while cell size tends to be similar (Rapoport et al., 2004), despite the fact that fruit growth, from the ovary to the mature fruit, is due in greater part to cell expansion than to cell division (Rapoport et al., 2004; Hammami et al., 2011). In fact, the mature fruit has about 8.5 times the cell number compared to the ovary, while cell size is about 250 times greater (Rapoport et al., 2004). Fruit weight is about 2000 (from 1000 to 4000) times greater than ovary weight at bloom (Rosati et 
al., 2009). However, from the ovary to the mature fruit, the mesocarp grows much more than the endocarp (Rosati et al., 2012), probably due to its longer growth period (i.e. up to fruit maturity) compared to the endocarp, which stops growing about eight weeks after bloom (Hammami et al., 2011). However, both tissues grow in strict proportion to their initial cell number in the ovary. The greater growth of the mesocarp is related to its initial (i.e. in the ovary at bloom) greater number of cells of smaller size (Rosati et al., 2012). These results agree with the hypothesis that cell number, rather than tissue mass, is related to the sink strength of an organ (Ho, 1992) even though this might be not always the case (Marcelis, 1996), because cell number is only one factor determining sink strength (Gillaspy et al., 1993).

Mature fruit size correlates with flower and, particularly, ovary size at bloom (Rosati et al., 2009). This is true for both the mesocarp and the endocarp independently, though, as stated above, the mesocarp grows proportionally more: the endocarp volume in the fruit is about 4000 times greater than its volume in the ovary, while the same ratio is about 800 for the endocarp (Rosati et al., 2012).

Both the endocarp and mesocarp contribute to the ovary size differences among and within cultivars and even the locular space is proportional to ovary size (Rosati et al., 2012). Similarly, proportionality among the ovary and other flower parts was found both within trees (Cuevas \& Polito, 2004) and between cultivars (Rosati et al., 2009). Ovary size depends mostly on cell number rather than size, both across and within cultivars (Rosati et al., 2011a). This is true both for the mesocarp and the endocarp, suggesting that similar mechanisms regulate cell division in different tissues. Cell size does differ among cultivar, but does not correlate with ovary size. Cell size differs greatly among tissues with bigger but fewer cells in the endocarp compared to the mesocarp, suggesting that cell growth patterns differ among tissues (Rosati et al., 2011a). In fact, cell size in the ovary correlates with tissue relative growth (i.e. from bloom to fruit maturity), both across tissues and cultivars, suggesting that cell size at bloom reflects the stage of growth of a given tissue: the larger the cells, the less growth remains to be performed (Rosati et al., 2012). This agrees with the observation that fruit growth is mostly achieved by cell expansion as mentioned above. The larger cell size of the endocarp at bloom suggests that this tissue is at a more advanced stage of growth, compared with the mesocarp and thus, its remaining growth, relative to its size at bloom, is less, at least in terms of cell expansion. This would also explain why the endocarp stops growing earlier than the mesocarp. It is possible that the endocarp might be in a more advanced stage of development at bloom, since it is inside this tissue that vital functions (e.g. fertilisation) take place soon after bloom and thus the endocarp needs relatively more differentiated cells. The mesocarp, on the contrary, does not perform particular activities at bloom, hence, it does not need advanced cell differentiation in this period.

In conclusion, genetic differences in fruit size, among olive cultivars, appear to arise from differences in cell division patterns occurring in the ovary (and probably in the whole flower) before bloom. Similar results have been found in other species where genes coding for cell division before bloom have been found to be responsible for differences in final fruit 
size. The final fruit size, aside from genetic control, is also related to environmental and endogenous plant conditions that allow the genetic potential growth to be achieved to a varying degree. Analysis the genomics, or of environmental factors affecting fruit size is beyond the scope of this review.

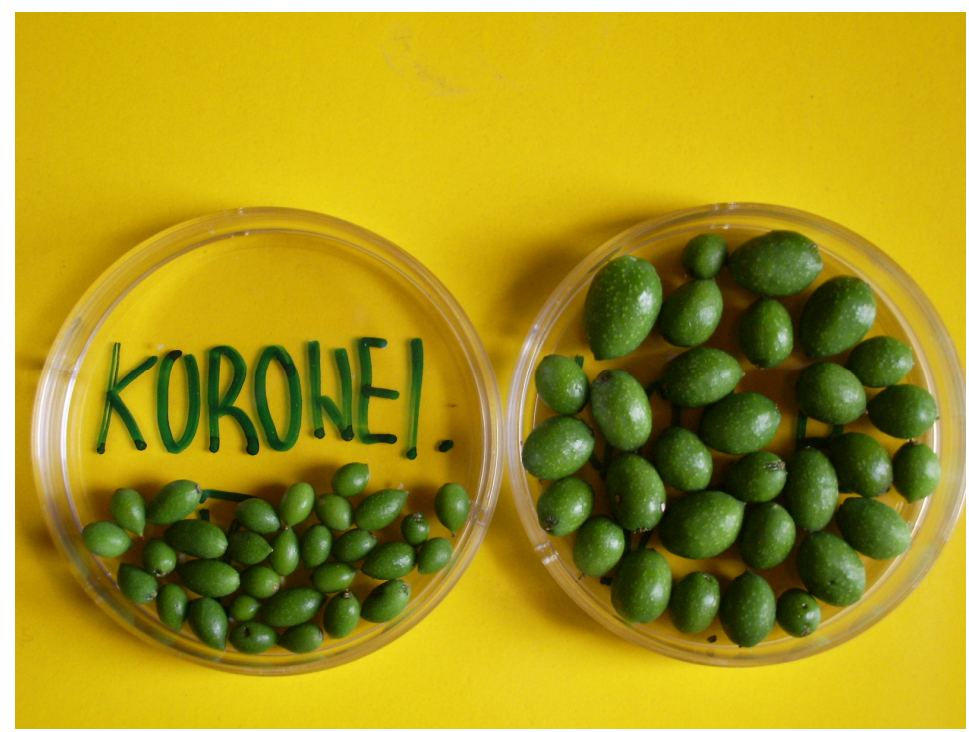

Figure 2. Fruit size differing in olive cultivars: Nocellara del Belice, a large-fruited cultivar, on the right, and Koroneiki, a small-fruited cultivar, on the left at the same date during the fruit growth cycle. The difference was already present among the ovaries at bloom.

\section{Ovary (or pistil) abortion}

Ovary or pistil abortion indicates the presence of flowers with absent or only partly formed and non-viable ovaries: that is, ovaries incapable of becoming fruits and destined to drop. Flowers with aborted ovaries are often called staminate flowers since only the male organs are complete and functional. Normal flowers with both male and female organs complete and functional are called hermaphrodite flowers. Ovary abortion varies greatly with year, cultivar, individual tree, branch and shoot, and even among and within inflorescences (Morettini, 1939; Bottari, 1951; Badr \& Hartmann, 1971; Fabbri et al., 2004; Martin \& Sibbett, 2005). Ovary abortion occurs early during flower development, (Pirotta \& De Pergola, 1913), mostly 30-40 days before bloom (Uriu, 1959; Cuevas et al., 1999; Reale et al., 2006).

Ovary abortion in olive appears to results mostly from competition among flowers (and ovaries, the future fruits) for resources, which are insufficient for all flowers to develop, given the redundant flowering. The onset of this competition occurs very early and affects both pistil abortion and fruit set, as we will see later (Hartmann, 1950; Uriu, 1959; Cuevas et al., 1994; Perica et al., 2001; Levin \& Lavee, 2005). Conditions that affect competition among 
flowers/fruits or that decrease available resources, usually result in increased abortion and decreased fruit set. Among such conditions are: $\mathrm{N}$ deficiency, foliar diseases and low leaf-tobud ratio, (Petri, 1920; Morettini, 1951; Uriu, 1953, 1959; Fernandez-Escobar et al., 2008); water stress (Melis, 1923; Brooks, 1948; García Gálvez, 2005); insufficient light (Bottari, 1951; Dimassi et al., 1999); adverse climactic conditions and high yield in previous year (Rallo et al., 1981; Rapoport \& Rallo, 1991; Lavee, 1996; Cuevas et al., 1994); abundant flowering in current year (Reale et al., 2006); and unfavorable inflorescence position in the canopy (Cuevas \& Polito, 2004; Seifi et al., 2008). Aborted flowers do not contain starch, suggesting a link between nutrient availability and pistil abortion (Reale et al., 2009). Removing part of the inflorescences reduces drastically the ovary abortion in olive (Seifi et al., 2008).

On the other hand, pistil abortion is known to be under genetic control, varying with the cultivar (Campbell, 1911; Morettini, 1939, 1951; Magherini, 1971; Lavee, 1996; Lavee et al., 2002). In a recent paper it has been demonstrated that even the genetic component can be interpreted with the competition theory (Rosati et al., 2011b). In fact, as described above, fruit size differences are related to ovary size differences among cultivars. Large-fruited cultivars tend to have bigger flowers, not just ovaries (Rosati et al., 2009). This implies greater energetic costs for the same number of flowers, and thus greater pistil abortion, which in fact tends to be higher in larger-fruited cultivars (Morettini, 1939; Magherini, 1971; Acebedo, 2000; Rosati et al., 2011b). In the previous paragraph we have seen that greater ovary size in large-fruited cultivars results from greater cell number (not greater cell size) and cell number appears to be a key factor in determining the sink strength of an organ (Marcelis, 1996). Larger ovaries with more cells, therefore, might have a greater ability to compete for resources than smaller ovaries, determining both greater abortion and lower fruit set.

\section{Fruit set}

As mentioned above, fruit set is very low in olive (Hartmann, 1950). It is often believed that positively affecting it (i.e. reducing it) would lead to greater yields. However, many studies show that when flower numbers are artificially reduced, fruit set increases proportionally, leading to similar numbers of set fruits (Suarez et al., 1984, Rallo \& Fernandez-Escobar, 1985, Lavee et al., 1996, 1999). This is interpreted as a tendency of the olive tree to set a fixed mass of fruits, that is independent of flower number. This fixed mass is referred to as the fruiting potential (Lavee et al., 1996), and depends on the genotype and environmental factors. Hence, as soon as fruit set reaches such potential, based on tree reserves, the rest of the flowers may drop.

Competition for resources among flowers in olive is reported in many studies (Suarez et al., 1984; Cuevas et al., 1994; Lavee et al., 1999; Seifi et al., 2008; Rapoport \& Rallo, 1991; Cuevas et al., 1995). Rugini and Pannelli (1993) showed that fruit set increases when shoot development is mechanically or chemically slowed down, further supporting the hypothesis that competition drives fruit set. Given that resource availability affects fruit set, largefruited cultivars, having larger ovaries/flowers (Rosati et al., 2009), which need more resources, set fewer fruits, though total fruit mass is similar (Rosati et al., 2010). This 
suggests compensation between fruit number and size. The genetic effect on fruit set, appears thus to result from different degrees of competition for resources among ovary/flowers of different sizes. This would explain why small-fruited cultivars like Arbequina and Arbosana tend to produce several fruits per inflorescence, while table-olive (i.e. large-fruited) cultivars typically produce only one, but bigger fruit. Nor can it be argued that the small size in small-fruited cultivars is the result of a higher fruit set and consequent source limitations. In fact, aside from the fact that the fruit of these small-fruited cultivars is smaller already at bloom (i.e. the ovary), well before fruit set is decided, thinning fruits to reduce competition increases fruit size minimally, but does not result in fruit size comparable to that of large-fruited cultivars (Rosati et al., 2010). This suggests that differences in fruit size are mainly of genetic origin. Clearly, the ultimate fruit size depends also on resource availability, and varies up to more than $100 \%$ within the same cultivar, but among cultivars fruit size may vary much more than that (Barranco, 1999), up to 600\% (Rosati et al., 2009). Hence, adjusting fruit load across cultivars with extremely different fruit size needs a wider compensation mechanism than just adjusting fruit size: this mechanism appears to be the adjustment of fruit set.

\section{Redundant flowering, andromonecy and fitness}

As stated above, the olive produces redundant flowers relative to its yield potential and fruit set is very low. We have seen how ovary abortion increases under conditions that increase competition for resources. In fact, ovary abortion is a means to save resources, balancing the number of ovaries to the resources available (Primack \& Lloyd, 1980; Bertin, 1982; Stephenson \& Bertin, 1983). Plants, like the olive, that abort part of the ovaries in otherwise hermaphrodite flowers are called andromonoecious (about 4000 species are estimated to be andrommonoecious). From an evolutionary point of view, andromonoecy is considered an intermediate step towards dioecy, and allows saving of resources without affecting the total number of flowers and thus the male function and fitness (Vallejo-Marín \& Rausher, 2007). Aborting the ovary does not affect pollen production in olive (Cuevas \& Polito, 2004). In this species, large-fruited cultivars have greater ovary abortion, but similar number of flowers (Rosati et al., 2010, 2011b), leaving the male function probably unaltered (although differences in pollen production per flower, among cultivars with different fruit/ovary/flower size have not been studied). Leaving the male function (and fitness) unaltered might explain why only the ovary is aborted instead of the whole flower, which would save more resources, given that the flower is several times bigger than the ovary alone (Rosati et al., 2009; Cuevas \& Polito, 2004). It would also explain why the flower production is so redundant compared to the fruiting potential. Producing pollen is less expensive than producing fruits and seeds, while still increasing the plant's fitness, making it more convenient to produce more (male) flowers that fruits. Modeling work demonstrates that fitness is maximized, under limiting resources, when many more flowers than fruits are produced (Morgan, 1993). This author finds that the optimal flower/fruit ratio increases for andromonoecious and monoecious species compared to dioecious ones, and increases even more for wind pollinated species, like the olive. 
To increase olive productivity, therefore, it might be possible to breed plants that invest less in male fitness (reduced flowering), thus saving resources, which can be spend in setting and maturing more fruits. This appears reasonable since the energetic cost of flowering is not negligible in olive (Famiani et al., unpublished data).

\section{Conclusions}

We have seen how competition for available resources among developing flowers and fruits plays a continuous role during the whole developmental cycle of the reproductive organs (Lavee et al., 1999). Hence, pistil abortion first, and fruit set afterwards, appear to be part of a single mechanism that adjusts maternal investments to available resources. Even the genetic component affecting fruit size (i.e. cultivar differences) may be explained with the competition theory, based on the related differences in flower and ovary size (which correlates with fruit size), implying different energetic costs for the development of one fruit. In the absence of catastrophic events that might impair production (e.g. lack of pollination, severe drought or nutrient deficiency, etc.), the olive tree appears to produce fruits according to its potential, independent of the amount of flowers produced. To achieve this potential, the tree uses the different compensatory mechanisms available at any given developmental stage (i.e. pistil abortion, fruit drop, fruit size). Hence, studies reporting positive correlations between abundance of flowering (or pollen in the air) and yield (Moriondo et al., 2001; Fornaciari et al., 2002, Galán et al., 2004), would imply not a causal relationship but simply correlated phenomena: bloom and yield both represent an expression of the tree yield potential. The redundant flowering in olive, may serve the purpose of increasing the mail and the overall fitness, which is advantageous from an evolutionary point of view, but wasteful from an agronomical perspective. For the olive grower, selecting for reduced mail fitness (i.e. fewer flowers) to benefit the female fitness (i.e. yield) might prove beneficial.

\section{Author details}

Adolfo Rosati, Silvia Caporali and Andrea Paoletti

Agricultural Research Council - Olive Growing and Oil Industry Research Centre, Spoleto (PG), Italy

\section{Acknowledgment}

Financial support for this study was provided by the Italian Ministry of Agriculture, Food and Forestry Policy through the project GERMOLI "Salvaguardia e valorizzazione del GERMoplasma OLIvicolo delle collezioni del CRA-OLI".

\section{References}

Acebedo, M.M., Cañete, M.L. \& Cuevas, J. (2000). Processes affecting fruit distribution and its quality in the canopy of olive trees, Advances in Horticultural Science Vol. 14:169-175. 
Badr, S.A. \& Hartmann, H.T. (1971). Effect of diurnally fluctuating vs. constant temperatures on flower induction and sex expression in olive (Olea europaea L.), Physiologia Plantarum Vol. 24:40-45.

Barranco, D. (1999). Variedades y patrones, in Barranco, D., Fernàndez-Escobar, R., Rallo, L. (Eds), El cultivo del olivo, Ed. Mundi-Prensa, Madrid, pp. 63-89.

Bertin, R.I. (1982). The evolution and maintenance of andromonoecy, Evolutionary Theory Vol. 6:25-32.

Bertin, N., Gautier, H. \& Roche, C. (2002). Number of cells in tomato fruit depending on fruit position and source-sink balance during plant development, Plant Growth Regulation Vol. 36:105-112.

Bottari, V. (1951). Quattro anni di infruttuose osservazioni sull'aborto dell'ovario nel fiore dell'olivo, Annali della Sperimentazione Agraria Vol. 5: 359-376.

Brooks, R.M. (1948). Seasonal incidence of perfect and staminate olive flowers, Proceedings American Society of Horticultural Science Vol. 52:213-218.

Campbell, C. (1911). L'aborto fiorale nell'olivo, L'Italia Agricola, Vol. 16.

Corelli-Grappadelli, L. \& Lakso A.N. (2004). Fruit development in deciduous tree crops as affected by physiological factors and environmental conditions, Acta Horticulturae Vol. 636:425-441.

Cuevas, J., Rallo, L.\& Rapoport, H.F. (1994). Crop load effects on floral quality in olive, Scientia Horticulturae Vol. 59:123-130.

Cuevas, J., Rallo, L.\& Rapoport, H.F. (1995). Relationships among reproductive processes and fruitlets abscission in Arbequina olive, Advances in Horticultural Science Vol. 9:92-96.

Cuevas, J., Pinney, K.\& Polito, V.S. (1999). Flower differentiation, pistil development and pistil abortion in olive, Acta Horticulturae Vol. 474:293-296.

Cuevas, J.\& Polito, V.S. (2004). The role of staminate flowers in the breeding system of Olea europaea (Oleaceae): an andromonoecious, wind-pollinated taxon, Annals of Botany Vol. 93:547-553.

Dimassi, K., Therios, I.\& Balatsos, A. (1999). The blooming period and self-fruitfulness in twelve Greek and three foreign olive cultivars. Acta Horticulturae Vol. 474:275-278.

Fabbri, A., Bartolini, G., Lambardi, M. \& Kailis, S.G. (2004). Olive Propagation Manual, Landlinks Press, Collingwood, Victoria.

Fernandez-Escobar, R., Ortiz-Urquiza, A., Prado, M. \& Rapoport, H.F. (2008). Nitrogen status influence on olive tree flower quality and ovule longevity, Environmental and Experimental Botany Vol. 64:113-119.

Fornaciari, M., Pieroni, L., Orlandi, F. \& Romano, B. (2002). A new approach to consider the pollen variable in forecasting yield models, Economic Botany Vol. 56:66-72.

Galán, C., Vázquez, L., García-Mozo, H. \& Domínguez, E. (2004). Forecasting olive (Olea europaea) crop yield based on pollen emission, Field Crops Research Vol. 86:43-51.

García Gálvez, G. (2005). Calidad de flor del olivo en relación al régimen de riego y a la salinidad, Trabajo Professional Fin de Carrera, E.T.S.I.A.M., University of Cordoba, Spain.

Gillaspy, G., Ben-David, H. \& Gruissem, W. (1993). Fruits: A developmental perspective, Plant Cell Vol. 5:1439-1451.

Hammami, S.B.M., Manrique, T. \& Rapoport, H.F. (2011). Cultivar based fruit size in olive depends on different tissue and cellular processes throughout growth, Scientia horticulturae Vol. 130:445-451. 
Hartmann, H.T. (1950). The effect of girdling on flower type, fruit set, and yields in the olive, Proceedings American Society of Horticultural Science Vol. 56:217-226.

Ho, L.C. (1996). Tomato, in Zamki, E., Shaffer, A.A. (Eds.), Photoassimilate distribution in plant and crops, Marcel Dekker, Inc., New York, pp. 709-728.

Lavee, S. (1996). Biology and physiology of the olive, in IOOC (Eds.), World Olive Encyclopedia. International Olive Oil Council, Madrid, Spain, pp. 59-110.

Lavee, S., Rallo, L., Rapoport, H.F.\& Troncoso, A. (1996). The floral biology of the olive: effect of flower number, type and distribution on fruitset, Scientia horticulturae Vol. 66:149-158.

Lavee, S., Rallo, L., Rapoport, H.F. \& Troncoso, A. (1999). The floral biology of the olive II. The effect of inflorescence load and distribution per shoot on fruit set and load, Scientia horticulturae Vol. 82:181-192.

Lavee, S., Taryan, J., Levin, J. \& Haskal, A. (2002). The significance of crosspollination for various olive cultivars under irrigated intensive growing conditions, Olivae Vol. 91:2536.

Levin, A.G. \& Lavee, S. (2005). The influence of girdling on flower type, number, inflorescence density, fruit set, and yields in three different olive cultivars ('Barnea', 'Picual', and 'Souri'), Australian Journal of Agricultural Research Vol. 56:827-831.

Magherini, R. (1971). Osservazioni sull'aborto dell'ovario nell'olivo, L'Agricoltura Italiana Vol. 71:291-301.

Marcelis, L.F.M. (1996). Sink strenght as a determinant of dry matter partitioning in the whole plant, Journal of Experimental Botany Vol. 47:1281-1291.

Martin, G.C. \& Sibbett, G.S. (2005). Botany of the olive, in Sibbett, G.S., Ferguson, L., Coviello, J.L., Lindstrand, M. (Eds.), Olive Production Manual, University of California, Agriculture and Natural Resources, Oakland, California, pp. 15-19.

Melis, A. (1923). Cause di aborto nel gineceo del fiore dell'olivo, Stazione Sperimentale Agricola Italiana Vol. 56:302-312.

Morettini, A. (1939). L'aborto dell'ovario nel fiore dell'olivo, L'Italia Agricola Vol. 11:815-828.

Morettini, A. (1951). Ulteriore contributo allo studio dell'aborto dell'ovario nel fiore dell'olivo, Annali della Sperimentazione Agraria Vol. 5:309-329.

Morgan, M. (1993). Fruit to flower ratio and trade-pffs in size and number, Evolutionary Ecology Vol. 7:219-232.

Moriondo, M., Orlandini, S., De Nuntiis, P. \& Mandrioli, P.(2001). Effect of agrometeorological parameters on the phenology of pollen emission and production of olive trees (Olea europea L.), Aerobiologia Vol. 17:225-232, DOI: 10.1023/A:1011893411266.

Perica, S., Brown, P.H., Connell, J.H., Nyomora, A.M.S., Dordas, C., Hu, H.N.\& Stangoulis, J. (2001). Foliar boron application improves flower fertility and fruit set of olive, HortScience Vol. 36,714-716.

Petri, L. (1920). Sulle cause di arresto di sviluppo dell'ovario nel fiore dell'olivo, Rendiconti dell'Accademia Nazionale dei Lincei Vol. 29, serie 5, sem. I.

Pirotta, R.\& De Pergola, D. (1913). Sull'olivo maschio, Bollettino della Società Botanica Italiana Vol. 20.

Primack, R.B.\& Lloyd, D.G. (1980). Andromonoecy in the New Zealand montane shrub manuka, Leptospermum scoparium (Myrtaceae), American Journal of Botany Vol. 67:361368. 
Rallo, L., Martin, G.C. \& Lavee, S. (1981). Relationship between abnormal embryo sac development and fruitfulness in olive, Journal of the American Society for Horticultural Science Vol. 106:813-817.

Rallo, L. \& Fernandez-Escobar, R. (1985). Influence of cultivar and flower thinning within the inflorescence on competition among olive fruit, Journal of the American Society for Horticultural Science Vol. 110:303-308.

Rapoport, H.F. \& Rallo, L. (1991). Postanthesis flower and fruit abscission in 'Manzanillo' olive, HortScience Vol. 116:720-723.

Rapoport, H.F., Manrique T. \& Gucci, R. (2004) Cell division and expansion in the olive fruit, Acta Horticulturae Vol. 636:461-465.

Reale, L., Sgromo, C., Bonofiglio, T., Orlandi, F., Fornaciari, M., Ferranti, F. \& Romano, B. (2006). Reproductive biology of Olive (Olea europaea L.) DOP Umbria cultivars, Sexual Plant Reproduction Vol. 19:151-161.

Reale, L., Sgromo, C., Ederli, L., Pasqualini, S., Orlandi, F., Fornaciari, M., Ferranti, F. \& Romano, B. (2009). Morphological and cytological development and starch accumulation in hermaphrodite and staminate flowers of olive (Olea europaea L.), Sexual Plant Reproduction Vol. 22:109-19.

Rosati, A., Zipanćič, M., Caporali, S. \& Padula, G. (2009) Fruit weight is related to ovary weight in olive (Olea europaea L.), Scientia Horticulturae Vol. 122:399-403.

Rosati, A., Zipanćič, M., Caporali, S. \& Paoletti, A. (2010). Fruit set is inversely related to flower and fruit weight in olive (Olea europaea L.), Scientia Horticulturae Vol. 126:200-204.

Rosati, A., Caporali, S., Hammami, S.B.M., Moreno-Alias, I., Paoletti, A.\& Rapoport, H.F. (2011a). Differences in ovary size among olive (Olea europaea L.) cultivars are mainly related to cell number, not to cell size, Scientia Horticulturae Vol. 130:185-190.

Rosati, A., Caporali, S., Paoletti, A. \& Famiani, F. (2011 b). Pistil abortion is related to ovary mass in olive (Olea europaea L.), Scientia Horticulturae Vol. 127:515-519.

Rosati, A., Caporali, S., Hammami, S.B.M., Moreno-Alías, I., Paoletti, A. \& Rapoport, H.F. (2012). Tissue size and cell number in the olive (Olea europaea) ovary determine tissue growth and partitioning in the fruit, Functional Plant Biology, in press.

Rugini, E. \& Pannelli, G. (1993). Preliminary results on increasing fruit set in olive (Olea europaea L.) by chemical and mechanical treatments, Acta Horticulturae Vol. 329:209-210.

Seifi, E., Guerin, J., Kaiser, B. \& Sedgley, M. (2008). Inflorescence architecture of olive, Scientia Horticulturae Vol. 116:273-279.

Stephenson, A.G. \& Bertin, R.I. (1983). Male competition, female choice and sexual selection in plants, in Real, L., (ed.), Pollination Biology, London, Academic Press, pp. 109-149.

Suarez, M.P., Fernandez-Escobar, R. \& Rallo, L. (1984). Competition among fruits in olive II. Influence of inflorescence or fruit thinning and cross-pollination on fruit set components and crop efficiency, Acta Horticulturae Vol. 149:131-144.

Uriu, K. (1953). Pistil abortion in the olive (Olea europaea L.) as influenced by certain physiological conditions. PhD Thesis, University of California, USA.

Uriu, K. (1959). Periods of pistil abortion in the development of the olive flower, Proceedings American Society of Horticultural Science Vol. 73:194-202.

Vallejo-Marín, M. \& Rausher, M.D. (2007). The role of male flowers in andromonoecious species: energetic costs and siring success in Solanum carolinense L., Evolution Vol. 61:404-412. 